\title{
Determinants of Owner-manager Competencies for Small Business Operations: Evidence from a Small Restaurant Business in Tanzania
}

\section{Ruth Elias ${ }^{\text {i }}$ \\ Wilhelm Leonard ${ }^{2}$ Joshua Mwakujonga ${ }^{3}$}

'School of Business Studies, University of Dodoma, Dodoma, Tanzania Emaileliasruth75@omail.com Tel.+25.5715220087

${ }^{2}$ School of Public Administration and Management, Mzumbe University, Morogoro, Tanzania EmailWilhelm.mafuru@gmail.com Tel:+255652768873

${ }^{3}$ Department of Business Studies, Mzumbe University, Dar Es Salaam Campus College, Tanzania Emailmjoshua@mzumbe.ac.tz Tel: +255685860656

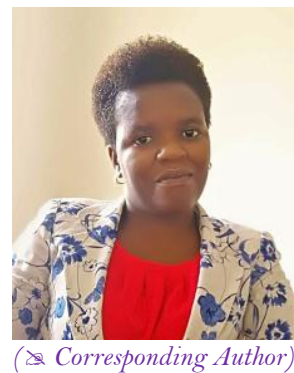

(A) Check for updates

Abstract

This study examines the influence of owner-manager demographic characteristics on attainment of their competencies in Tanzania, because there are scant empirical evidences on the same. The data used in this study were obtained through a survey of 392 small restaurant businesses from Ilala and Dodoma in Tanzania. Information was collected from the owner-managers of these entities by using structured questionnaires. Competencies of the owner-managers were measured subjectively by assessing their ability to perform entrepreneurial, managerial and functional works. Thus, the study uses Structural equation model to analyze the latent variable data collected. Study results have shown that among the demographic characteristics of the ownermanager, formal education and family background in doing business are more important in explaining how competent an owner-manager is in all three competencies. Furthermore, age of the owner-manager is very important in explaining how competent the owner-manager is in terms of managing the business while their industrial working experiences are more important in explaining the owner-manager ability to fulfill functional activities. These results imply that, whoever wants to operate the small restaurant business should try to understand their demographic characteristics. That is, to match themselves with the competencies of fulfilling entrepreneurial, managerial and functional activities or decide on any other way of compensating for their weaknesses for better business performances.

Keywords: Owner-manager, Demographic characteristics, Entrepreneurial, Managerial, Functional, Competencies. JEL Classification: M5, M10, J1, M13.

\section{Introduction}

In order for a business to perform successfully for a long term, individual competencies as the determinant tool to the performance of businesses should be ensured by the owner-manager's competence in the entrepreneurial, managerial and functional areas (Becker, 1964; Bird, 1995; Frese, 2000; Ahmad et al., 2011). The determinant on how the individual attains competencies to affect the business depends on several issues. Literature shows that demographic characteristics like education, work and life experiences of an individual can help to attain competencies that are suitable for the business organization which could become the contribution of the individual towards a successful performance for the organization (Walker et al., 2007). To make use of attained competencies, employees of the large organization are selected through interviews based on individuals with best competence that suits the position being applied for and are backstopped with customized training and workshops that help to determine their competencies to perform (Samwel, 2018).

Small business has its different experience; the competencies to perform are based on owner-manager himself. Unfortunately, in the majority of small businesses owner-managers initiate the business without strategically being interviewed if they have or not any competencies for the business performance before initiating the business (Webster et al., 2005). For most of the owner-managers, their prime motive in initiating a business is to earn income as an alternative survival endeavor after being disqualified from the established competences of formal employments (Walker et al., 2007). It is also acknowledged that small business owner-managers have low formal education levels compared to managers of larger businesses, and they participate less in competency development and training activities (Billett, 2001; Bartram, 2005). Furthermore, just by the fact that most of small restaurant businesses are dominated by owner-managers with no profession of restaurant management and many of whom have been disqualified from formal employment, their businesses are merely alternative survival endeavors to 
simply fulfill their needs; hence their determination towards attainment of required owner-manager entrepreneurial, managerial and functional performance competencies appear different.

Despite their inclusiveness to the wider range of society they serve in terms of self - employment, provision of services and an extended employment opportunity that preserves the local economic development of the country, for the small businesses, in which competence to perform is based on the owner-managers, their determinants has not been visualized (Bird, 2002; Inyang and Enuoh, 2009). As a result, most of these businesses suffer the entry and exit syndrome, but also can hardly advance to medium or large size (Tundui, 2012).

This study values the importance of owner-manager competence for necessary performance of the business operation. They are only vision bearer for performance and long-term success in their small businesses. Owner manager competence in terms of knowledge, skills and attitude are acquired through intuition and by learning to which this study demonstrates how the demographic characteristic can determine owner manager entrepreneurial, managerial and functional competencies (Becker, 1964; Bird, 1995; Ahmad et al., 2011). This will help the ownermanager and the government to arise in facilitation of the development of small businesses. Therefore, this article aims at providing empirical evidence from Tanzania on the extent to which demographic characteristics owned by the owner-manager influence the attainment of the entrepreneurial, managerial and functional competencies.

\section{Literature Review}

The characteristics of the owner-manager has been regarded as the most influential factors toward the attainment of the individual competencies (Becker, 1964; Bird, 1995; Ahmad, 2007; Santos, 2011). There has been reliable evidence that one factor results into different development of competencies basing on the learning environment and other individual characteristics (Reuber and Fischer, 1994; Quińones et al., 1995). Therefore, demographic factors such as industrial working experiences, formal education, and family background in doing business, age and sex of the owner-manager have been discussed in relation to the attainment of the competencies necessary for business performances.

\subsection{Industrial Work Experience}

Theoretically, industrial work experiences influence the attainment of individual competencies (Becker, 1964). Literature also shows that industrial working experience helps the individual to learn by doing and with the accumulated practices, to attain the necessary competencies (Dyke et al., 1992; Sarwoko et al., 2013). However, these researches did not show clearly the contribution of industrial working experiences to each competency required by owner-managers. Basing on the fact that small restaurant business is operated by an individual, and each competency contributes differently to the performance of the business, the determinants of entrepreneurial, managerial and functional competencies which have been neglected for long are still more important to find out (Ahmad, 2007; Wickramaratne et al., 2014).

\subsection{Formal Education}

Human capital theory states that education is one of the key investments that influences the attainment of owner's competencies (Becker, 1964). When an owner increases his/her education level, $\mathrm{s} /$ he is expected to gain more stock of human knowledge which increases the ability to run the business successfully (Mitchelmore and Rowley, 2010; Sarwoko et al., 2013; Mahadalle and Kaplan, 2017). However, it is difficult to generalize these findings as the attainment of competencies from education investment depends on the type of competencies to be attained and the education environment (Reuber and Fischer, 1994; Quińones et al., 1995). This study therefore, goes far in contributing to the literature, the effect of formal education on attainment of entrepreneurial, managerial and functional competencies.

\subsection{Family Background in Doing Business}

Individuals determine their own social and personal value based on how we stack up against others (Festinger, 1954). Children determine their competencies from their referees who are the parents or guardians. Evidence indicates that, some of owner-manager competencies are learned and acquired through observing parents and relatives doing business or through participating in the family business (Niittykangas and Tervo, 2005; Mungai and Velamuri, 2011). This study also aimed at finding the influence of family background in doing business on the attainment of owner-manager competencies.

\subsection{Age of the Owner-Manager}

Age has been an important characteristic used as one of the important variables in grouping individuals in a contemporary social science research and explains differences among them. Literature shows that, older ownermanagers are logically expected to attain more necessary competencies because they have more of experience, have gone through many challenges, which make them strong and confident (Raposo et al., 2008; Isaga, 2012). In contrast, evidence shows that younger owner-managers are more energetic, have higher ambitions and are more probable to be dedicated to working long hours, which are generally necessary competencies for business performance (Storey, 1994; Woldie et al., 2008). On the other way, Storey (1994) showed that middle-aged individuals are comparatively likely to be experienced and more energetic to work than younger or older ownermanagers. What is not yet clear is at what age the owner-manager archives all necessary competencies for business performance. This calls for more research in order to understand more the various differences in age of the ownermanager at which owner attains the required entrepreneurial, managerial, and functional competencies.

\subsection{Sex of the Owner-Manager}

Literature indicated various demographic variables as the factors influencing owner's competencies, but very few studies considered the influence of sex on the attainment of owner's competencies (Sajilan et al., 2015). A research indicates that male and female have different socialization experiences, which shape their behaviour 
towards the operation of the business. Furthermore, females have less competency to operate a business than males (Raposo et al., 2008). Thus, these differences predicted to affect the ability to attain competencies in operating the business (Díaz-García and Jiménez-Moreno, 2010; Yordanova and Tarrazon, 2010; Kefale and Chinnan, 2012). Futhermore, researchers indicate that, male and female are reported to have different motives and perception in initiating a business (Manolova et al., 2007). Females are said to have low motives toward the business compared to males. The kind of motivation an individual has affects development of competencies for business performance (Ali and Mahamud, 2013). Therefore, differences in motives in initiating a business lead to the different efforts in developing competencies (Cliff, 1998). For example, females perceiving business as a cooperative network, they make themselves to have more of managerial competencies in the business than males (Madichie and Gallant, 2012).

\section{Methodology}

\subsection{Research Approach and Design}

This study examines the influence of owner-manager demographic characteristics on the acquisition of the competencies necessary for performance of small restaurant businesses by using the quantitative method approach. Since this is a population-based survey, we have used cross sectional design to collect data on the entire study population.

\subsection{Sampling}

Our study surveyed a random sample of 392 entities from 459 small restaurant businesses with the specified criteria within the municipalities. Moreover, to avoid the diversity of the results, owner-managers were selected from the small restaurant business with 1-10 employees, with a 5-20 million capital and being in operation for at least three years and not more than 10 years. This is because most of the owner-managers are found within the business with such characteristics. Furthermore, within this range of business characteristics, owner-manager competencies are more needed than in large businesses where there are more of specialized employees with necessary competencies who can assist the owner. The selection of the small restaurant businesses was from the original list of licensed small restaurants businesses within Ilala and Dodoma municipality.

\subsection{Structured Questionnaire}

Since this is a survey based research, data was collected through a structured questionnaire. Moreover, proper questionnaires design is vital for data quality and minimisation of the measurement error. Therefore, as the interview involved owner-manager within the local community, the common language used is "Kiswahili". Furthermore, after the design of the survey questionnaire, the instrument was subjected to pilot study in order to; first, guarantee the reliability of study results; second, ensure clarity and relevance of research instruments and methodology; third, test if the variables and measures were suitable. The pilot study was followed by refinement of the questionnaire; the original questionnaire was subjected to changes as per correction from the pilot study. The following changes were made; shortening of questionnaire and questions which were found to be ambiguous were dropped. Furthermore, refining the questionnaire which included, rephrasing and sequencing of questions was taken into account to ensure that all respondents have a common understanding of the questions.

\subsection{Owner-Manager Competencies}

Competencies are overall necessary skills and knowledge owned by an individual for the betterment of the performance. It is the ability of the individual to conduct the specified activities successfully. Owner-manager competency measures have been adopted from Man (2001) and grouped as proposed by Ahmad et al. (2011). Therefore, this study has measured the owner-manager competencies basing on the three main responsibilities of an owner-manager in the business. That is, entrepreneurial, managerial and functional competencies.

For the purpose of this article, and taking into account the above explanation, owner-manager competencies articulated in terms of entrepreneurial, managerial, and functional is the dependent variable. This measure required the owner-manager to indicate their level of agreement on being able to undertake the described entrepreneurial, managerial and functional activities. Five scales were used for this purpose: strongly disagree, disagree, neither agree nor disagree, agree, strongly agree. For that way, they were indicating the competency they have for performing prescribed activities.

The Independent Variables include the variables representing formal education, industrial working experience, and family background in doing business, age and sex of the owner-manager. Their measurement are given in table below

Table-1. Measurement of the variable

\begin{tabular}{l|l|l}
\hline & $\begin{array}{l}\text { Independent variable: } \\
\text { manager demographic characteristics }\end{array}$ & Measurement \\
\hline 1 & Formal education & Categorical variable measured in level of education \\
\hline 2 & Industrial work experience & $\begin{array}{l}\text { Continuous variable measured in years of experience in } \\
\text { food related businesses }\end{array}$ \\
\hline 3 & Family background in doing business & $\begin{array}{l}\text { Dummy variable measured as the owner-manager having } \\
\text { a family background in doing business as Yes or No }\end{array}$ \\
\hline 4 & Age of the owner-manager & $\begin{array}{l}\text { Continuous variable measured as the time of life of the } \\
\text { owner-manager in terms of years since born. }\end{array}$ \\
\hline 5 & Sex of the owner-manager & $\begin{array}{l}\text { Dummy variable measured as the sex of the owner- } \\
\text { manager, either male or female. }\end{array}$ \\
\hline
\end{tabular}

Source: Developed from Literature Review, 2017 


\subsection{Model Specification}

The objective of the study was to examine the influence of owner-manager characteristics on acquisition of owner-manager competencies. Basing on the nature of the study variable, specifically on the nature of dependent variable (owner-manager competencies) the structural equation modeling (SEM) was found to be appropriate for data analysis of this research. SEM has been used since it has the ability to model the relationship that has the unobserved variable. Furthermore, it has the advantage of examining complex patterns of relationship among the construct in an integrative way.

Structural Equation Modeling (SEM) was perfumed through the STATA 15 software. SEM is the technique that combines confirmatory factor analysis (CFA) and regression analysis. CFA is the process of validating latent (unobserved) construct. Since the study objectives include the latent variable (owner-manager competencies) the researcher performed CFA for the latent constructs in the study before modeling their inter-relationship in SEM by using regression analysis.

\section{Results and Discussion}

\subsection{Confirmatory Factor Analysis}

To examine the influence of owner-manager demographic characteristics on the attainment of their competencies; we first run confirmatory factor analysis among the owner-manager competencies (entrepreneurial, managerial and functional) construct. Confirmatory factor analysis was meant to test whether the measures of these construct are consistent with the researcher's understanding of the nature of that construction. Likewise, all measurement models must be validated and accepted prior to modeling the structural model.

Table-2. The CFA report for every construct in the model

\begin{tabular}{|c|c|c|}
\hline Construct & Item & Factor Loading \\
\hline \multirow{6}{*}{$\begin{array}{l}\text { Entrepreneurial } \\
\text { competency }\end{array}$} & Processing food and services that customer wants & 0.93 \\
\hline & Processing food that brings benefit to customers & 0.98 \\
\hline & Sell food at a cheaper price & 0.99 \\
\hline & Take new problem as an opportunity & 0.99 \\
\hline & Assess the trend of small restaurant customers & 0.99 \\
\hline & Prioritize work in alignment with the business goal & 0.99 \\
\hline \multirow{7}{*}{$\begin{array}{l}\text { Managerial } \\
\text { competency }\end{array}$} & Lead employees & 0.98 \\
\hline & Motivate employees & 0.99 \\
\hline & Delegate & 0.94 \\
\hline & Interact with customers & 0.89 \\
\hline & Networking & 0.99 \\
\hline & Use of business support services & 0.96 \\
\hline & Family support & 0.90 \\
\hline \multirow{5}{*}{$\begin{array}{l}\text { Functional } \\
\text { competency }\end{array}$} & Use modern processing facilities & 0.92 \\
\hline & Use special knowledge in food processing & 0.93 \\
\hline & Offering delivery services & 0.90 \\
\hline & Visibility during processing of food & 0.95 \\
\hline & Design restaurant environment & 0.92 \\
\hline
\end{tabular}

In this study, we had 3 dimensions which are entrepreneurial competencies (6), managerial competencies (7) and functional competencies (5). According to Awang et al. (2015) the factor loadings for each item should be 0.6 or higher for an established item. It is apparent from Table 2 that, factor loading are above 0.6. Therefore, confirmatory factor analysis shows that all of the 18 measuring items from three competencies are relevant and were retained for analysis.

The analysis goes on with the examination of the fitness indexes. Therefore, in order to retain or reject the hypothesized model, incremental fits, absolute fits and parsimonious fits were examined. The examination of the fitness indexes as presented in Table 3 below indicates that the indexes values obtained meet the required level of the model fit. Therefore, we confirmed that the data fit well the model.

Table-3. The Fitness Indexes for the polled Measurement Model

\begin{tabular}{l|l|l|l|l|l}
\hline & Name of category & Name by index & Index value & Level of acceptance & Comments \\
\hline $\mathbf{1}$ & Absolute fit & $\begin{array}{l}\text { Root mean square of error } \\
\text { approximation (RMSEA) }\end{array}$ & 0.075 & $<0.08$ & $\begin{array}{l}\text { The required level } \\
\text { is achieved }\end{array}$ \\
\hline $\mathbf{2}$ & Incremental fit & Turker-lewis index (TLI) & 0.929 & $\begin{array}{l}\text { The required level } \\
\text { is achieved }\end{array}$ \\
\hline $\mathbf{3}$ & Parsimonious fit & $\begin{array}{l}\text { Chi-square/degree of } \\
\text { freedom (Chisq/df) }\end{array}$ & 3.250 & $<0.90$ & $\begin{array}{l}\text { The required level } \\
\text { is achieved }\end{array}$ \\
\hline
\end{tabular}

\subsection{Structural Model}

After the fitness an index was archived, the study goes on modeling for structural equation model. The exogenous variable industrial work experience, family background, education level, age and sex of the ownermanager have been regressed to latent endogenous variable entrepreneurial, managerial and functional competencies in one structural model. 
Table-4. Results of the effect of owner-manager characteristics on development of owner-manager competencies

\begin{tabular}{|c|c|c|c|c|c|}
\hline & & Coef & Std.err & $\mathbf{z}$ & $P$ value \\
\hline \multirow[t]{6}{*}{ Entrepreneurial } & Age & -0.0145 & 0.0044 & -3.25 & 0.001 \\
\hline & $\begin{array}{ll}\text { Industrial } & \text { working } \\
\text { Experience } & \end{array}$ & -0.03363 & 0.01126 & -2.99 & 0.003 \\
\hline & Female & 0.00122 & 0.075955 & 0.02 & 0.987 \\
\hline & Secondary & 2.5132 & 0.1982 & 12.68 & 0.001 \\
\hline & $\begin{array}{l}\text { Collage/university } \\
\text { education }\end{array}$ & 2.2763 & 0.20588 & 11.06 & 0.001 \\
\hline & Family background (yes) & 0.1727 & 0.07497 & 2.30 & 0.021 \\
\hline \multirow[t]{6}{*}{ Managerial } & Age & 0.019 & 0.006 & 3.02 & 0.003 \\
\hline & $\begin{array}{ll}\text { Industrial } & \text { working } \\
\text { Experience } & \\
\end{array}$ & -0.036 & 0.015 & -2.27 & 0.023 \\
\hline & Female & 0.1709 & 0.1078 & 1.59 & 0.113 \\
\hline & Secondary & 3.09 & 0.27 & 11.34 & 0.001 \\
\hline & $\begin{array}{l}\text { Collage/university } \\
\text { education }\end{array}$ & 2.78 & 0.28 & 9.76 & 0.001 \\
\hline & Family background (yes) & 0.27 & 0.106 & 2.54 & 0.011 \\
\hline \multirow[t]{6}{*}{ Functional } & Age & -0.012 & 0.004 & -2.48 & 0.013 \\
\hline & $\begin{array}{ll}\text { Industrial } & \text { working } \\
\text { Experience } & \\
\end{array}$ & 0.028 & 0.012 & 2.33 & 0.020 \\
\hline & Female & -0.06 & 0.08 & -0.83 & 0.408 \\
\hline & Secondary & 1.870 & 0.212 & 8.79 & 0.001 \\
\hline & $\begin{array}{l}\text { Collage/university } \\
\text { education }\end{array}$ & 1.73 & 0.221 & 7.83 & 0.001 \\
\hline & Family background (yes) & 0.30 & 0.82 & 3.67 & 0.001 \\
\hline
\end{tabular}

We found that the variable with $\mathrm{P}$ value less than the conventional value of 0.05 and with positive coefficient contributes significantly to the attainment of owner-manager competencies.

\section{Discussion}

Our research objective focused on the determinants of owner-manager competencies. Our results support greatly the expected notion that secondary and college level education have positive effects with respect to attainment of owner-manager competencies both in terms of entrepreneurial, managerial and functional. These results are in accord with earlier observations which showed that competencies of small business owners can be improved through education programs (Ahmad, 2007; Mitchelmore and Rowley, 2010; Sarwoko et al., 2013). However, the results of this study are in contrast to the former reviewed literature, for instance Wickramaratne et al. (2014) who revealed a negative relationship of formal education competencies of the owner-manager. An explanation for this may be that well-educated owner-managers are expected to make logical decisions that might be advantageous in improving performance.

From the findings we observed that industrial working experiences of the owner-manager is important in explaining the attainment of functional competencies. The findings of this study might be related to the fact that, industrial work experience helps an owner-manager to learn specific ways of operating the specific business. It is encouraging to compare these findings with that revealed by Katozai (2005) and Nsubuga (2009) who revealed that as one acquires more work experience, s/he acquires more skills, techniques and methods specifically in improving performance capabilities. However, our results found negative relationship on the industrial working experiences and attainment of necessary entrepreneurial and managerial competencies. These results may be because; it takes owner-manager energy, creativity, risk taking and motivation to act like attaining such competencies. Also, this study speculates that, the result from this study can be caused by failure of the ownermanager to use previous experience.

The results also revealed that, there is a positive relationship between the owner-manager coming from the family with background in doing business and attainment of owner-manager competencies in terms of entrepreneurial, managerial and functional. This can be explained by the fact that, owner-managers who came from families with background of doing business are more likely to learn and adopt skills from their parents or guardians in the ways of operating the business. The findings of this study are in line with that of Niittykangas and Tervo (2005); Mungai and Velamuri (2011) who provided some evidence that the competencies of an individual toward performance in their business are obtained through observing their parents and relatives or through participating in the family business.

Our result also supports that there is positive and significant relationship on the influence of age of the ownermanager and the attainment of managerial competencies. It also shows that, the ability of the owner-manager to attain managerial competences increases slightly at age 24 until the age 36 where it sharply increases up to age 65 when it starts to decrease. A strong relationship between age of the owner-manager and managerial competencies has been reported in the literature (Littunen and Virtanen, 2006). This result may be explained by the fact that, as owner-manager gets older, he/she acquires more experiences from the business as well as from the family. However, age of the owner-manager negatively influences the attainment of entrepreneurial and functional competencies. This finding corroborates the idea that, as the age of the owner-manager increases risk aversion increases. The reason for this may have something to do with the old individual becoming incapable of handling the challenges of new technology, innovation, searching for markets and obsolescence of their education level. However, the results are different with Raposo et al. (2008) who showed that, with increased age, individuals get more entrepreneurial competencies in identifying opportunities. 
In relation to the variable sex, the result showed that in compared to male owner-manager; female ownermanagers have a negative significant relationship with the attainment of both competencies. For this result, this study considers it to be due to the difference in motives for initiating a business among male and female ownermanagers. It has been comparably shown that female owner-managers operate their business with lower motivation than their male counterparts. This is from the fact that, the motives to initiate the business derives the necessary efforts toward fulfilling it. The findings of this study are consistent with those of other studies which suggest that, women's skills and knowledge of entrepreneurial activities are below average (Naudé, 2013).

\section{Conclusion and Policy Implication}

The aim of the current study was to determine the influence of owner-manager demographic characteristics on attainment of their entrepreneurial, managerial and functional competencies. Based on survey data collected from 392 owner-managers of small restaurant businesses from two regions in Tanzania, it became clear that ownermanager with secondary and college level education and coming from families with a background in doing business have greater influence on the attainment of entrepreneurial, managerial and functional competencies. Specifically, male owner-manager influences the attainment of entrepreneurial and managerial competencies. In addition, age of the owner-manager influences the attainment of managerial competencies while industrial working experience and female owner-manager significantly influence the attainment of functional competencies.

The evidence from this study implies that attainment or failure to attain entrepreneurial, managerial and functional competencies can be traced back to demographic characteristics of the owner-manager. Therefore, whoever wants to start the small restaurant business should try to understand their strength and weaknesses that are coming from own demographic characteristics. In that way, it would be easier for owner-manager to match themselves with the task of running a business or decide on any other way of compensating for their weaknesses.

This research extends knowledge on the previous studies that the attainment of necessary entrepreneurial, managerial and functional competencies for small restaurant business performance is greater from owner-manager who comes from family with business experiences and has at least secondary education level. The study also contradicts the common opinion and previous research that industrial working experiences of the owner-manager are important in developing entrepreneurial and managerial competencies that are necessary for business performance. It is not only important for the owner-manager to have large number of years in industry experiences, but the ability to learn and acquire the competencies through that time.

It should also be noted that while the present study makes noteworthy contributions, there are important limitations which need to be considered for future research. The study findings are limited to the collection of the information on family background on doing business. The study did not cover the kind of the business the family was engaged on and whether the owner-manager participated in the business or only observed the family doing the business. It would be interesting to assess the effect of the kind of business the family was engaged in if the ownermanager actually participated in the business or only observed the family doing the business.

\section{References}

Ahmad, N.H., 2007. A cross cultural study of entrepreneurial competencies and entrepreneurial success in SMEs in Australia and Malaysia (Doctoral Dissertation).

Ahmad, N.H., T. Ramayah, C. Wilson and L. Kummerow, 2011. Is entrepreneurialcompetency and business success relationship contingent upon business environment? A studyof Malaysian SMEs. International Journal of Entrepreneurial Behavior and Research, 16(3): $182-203$.

Ali, A.Y.S. and H.A. Mahamud, 2013. Motivational factors and performance of women entrepreneurs in Somalia. Journal of Education and Practice, $4(17): 47-53$

Awang, Z., A. Afthanorhan and M.A.M. Asri, 2015. Parametric and non parametric approach in structural equation modeling (SEM): The application of bootstrapping. Modern Applied Science, 9(9): 58-67. Available at: https://doi.org/10.5539/mas.v9n9p58.

Bartram, T., 2005. Small firms, big ideas: The adoption of human resource management in Australian small firms. Asia Pacific Journal of Human Resources, 43(1): 137-154. Available at: https://doi.org/10.1177/1038411105050311.

Becker, G.S., 1964. Human capital. New York: Columbia University Press.

Billett, S., 2001. Increasing small business participation in vet: A "hard ask". Education+ Training, 43(8/9): 416-425. Available at: https://doi.org/10.1108/eum0000000006485.

Bird, B., 1995. Towards a theory of entrepreneurial competency. Advances in Entrepreneurship, Firm Emergence and Growth, $2(1): 51-72$.

Bird, B., 2002. Learning entrepreneurship competencies: The self-directed learning approach. International Journal of Entrepreneurship Education, 1(2): 203-227.

Cliff, J.E., 1998. Does one size fit all? Exploring the relationship between attitudes towards growth, gender, and business size. Journal of Business Venturing, 13(6): 523-542. Available at: https://doi.org/10.1016/s0883-9026(97)00071-2.

Díaz-García, M.C. and J. Jiménez-Moreno, 2010. Entrepreneurial intention: The role of gender. International Entrepreneurship and Management Journal, 6(3): 261-283. Available at: https://doi.org/10.1007/s1 1365-008-0103-2.

Dyke, L., E. Fischer and A. Reuber, 1992. An inter-industry examination of the impact of owner experience on firm market share. Journal of Small Business Management, 30(4): 72-87.

Festinger, L., 1954. A theory of social comparison processes. Human Relations, 7(2): 117-140. Available at: https://doi.org/10.1177/001872675400700202.

Frese, M., 2000. Success and failure of micro business owners in Africa: A psychological approach. Westport: Ouorum Books.

Inyang, B.J. and R.O. Enuoh, 2009. Entrepreneurial competencies: The missing links to successful entrepreneurship in Nigeria. International Business Research, 2(2): 62-71. Available at: https://doi.org/10.5539/ibr.v2n2p62.

Isaga, N., 2012. Entrepreneurship and the growth of SMEs in the furniture industry in Tanzania (Doctorates Dissertation, Vrije Universiteit Amsterdam).

Katozai, M.A., 2005. A comprehensive study of education for prospective headmasters and headmistresses. Lubner: Peshawar University Publisher.

Kefale, M. and K. Chinnan, 2012. Employment growth and challenges in small and micro enterprises Woldiya, North East Amhara region, Ethiopia. Educational Research and Essays, 1(2): 21-26.

Littunen, H. and M. Virtanen, 2006. Differentiating growing ventures from non-growth firms. The International Entrepreneurship and Management Journal, 2(1): $93-109$.

Madichie, N.O. and M. Gallant, 2012. Broken silence: A commentary on women's entrepreneurship in the United Arab Emirates. The International Journal of Entrepreneurship and Innovation, 13(2): 81-92. Available at: https://doi.org/10.5367/ijei.2012.0071.

Mahadalle, A. and B. Kaplan, 2017. Entrepreneurial characteristics and competencies as determinants of corporate performance: A study on small enterprises in Mogadishu, Somalia. International Journal of Research-Granthaalayah, 5(5): 243-254. 
Man, W.Y.T., 2001. Entrepreneurial competencies and the performance of small and medium enterprises in the Hong Kong services sector (Doctoral Dissertation, The Hong Kong Polytechnic University)

Manolova, T.S., N.M. Carter, I.M. Manev and B.S. Gyoshev, 2007. The differential effect of men and women entrepreneurs' human capital and networking on growth expectancies in Bulgaria. Entrepreneurship Theory and Practice, 31(3): 407-426. Available at: https://doi.org/10.1111/j.1540-6520.2007.00180.x.

Mitchelmore, S. and J. Rowley, 2010. Entrepreneurial competencies: A literature review and development agenda. International Journal of Entrepreneurial Behavior \& Research, 16(2): 92-111. Available at: https://doi.org/10.1108/13552551011026995.

Mungai, E. and S.R. Velamuri, 2011. Parental entrepreneurial role model influence on male offspring: Is it always positive and when does it occur? Entrepreneurship Theory and Practice, 35(2): 337-357.

Naudé, W., 2013. Development progress in Sub-Saharan Africa: Lessons from Botswana, Ghana, Mauritius and South Africa. Achieving Development Success: Strategies and Lessons from the Developing World. pp: 284-292.

Niittykangas, H. and H. Tervo, 2005. Spatial variations in intergenerational transmission of self-employment. Regional Studies, 39(3): 319332. Available at: https://doi.org/10.1080/00343400500087166.

Nsubuga, Y.K.K., 2009. Analysis of leadership styles and school performance of secondary schools in Uganda (Doctoral Dissertation, Nelson Mandela Metropolitan University).

Quińones, M.A., J.K. Ford and M.S. Teachout, 1995. The relationship between work experience and job performance: A conceptual and metaanalytic review. Personnel Psychology, 48(4): 887-910. Available at: https://doi.org/10.1111/j.1744-6570.1995.tbo1785.x.

Raposo, M., A. do Paço and J. Ferreira, 2008. Entrepreneur's profile: A taxonomy of attribu tes and motivations of university students. Journal of Small Business and Enterprise Development, 15(2): 405-418. Available at: https://doi.org/10.1108/14626000810871763.

Reuber, A.R. and E.M. Fischer, 1994. Entrepreneurs' experience, expertise, and the performance of technology-based firms. IEEE Transactions on Engineering Management, 41(4): 365-374. Available at: https://doi.org/10.1 109/17.364560.

Sajilan, S., N.U. Hadi and S. Tehseen, 2015. Impact of entrepreneur's demographic characteristics and personal characteristics on firm's performance under the mediating role of entrepreneur orientation. Review of Integrative Business and Economics Research, 4(2): $36-52$.

Samwel, J., 2018. Impact of employee training on organizational performance - case study of drilling companies in Geita, Shinyanga and Mara Regions in Tanzania. International Journal of Managerial Studies and Research, 6(1): 36-41. Available at: https://doi.org/10.20431/2349-0349.0601005.

Santos, R.A., 2011. Entrepreneurial competencies of young people and opportunities for their labour development in their region. The case of the Mayan zone named Royal Road of Campeche. Anahuac Mayab University.

Sarwoko, E., A. Surachman and D. Hadiwidjojo, 2013. Entrepreneurial characteristics and competency as determinants of business performance in smes. IOSR Journal of Business and Management, 7(3): 31-38. Available at: https://doi.org/10.9790/487x0733138 .

Storey, D.J., 1994. Understanding the small business sector. 1st Edn., London: Routledge.

Tundui, C., 2012. Survival, growth strategies and market share of women owned micro and small businesses in Tanzania. In International Journal of Business and Management, 7(8): 143-155. Available at: https://doi.org/10.5539/ijbm.v7n8p143.

Walker, E., J. Redmond, B. Webster and M. Le Clus, 2007. Small business owners: Too busy to train? Journal of Small Business and Enterprise Development, 14(2): 294-306. Available at: https://doi.org/10.1108/14626000710746718.

Webster, B., E.A. Walker and J. Turner, 2005. Smart training for the older entrepreneur. Proceedings of the 50th World Conference of ICSB, 15-18th June, Washington, ICSB

Wickramaratne, A., A. Kiminami and H. Yagi, 2014. Entrepreneurial competencies and entrepreneurial orientation of tea manufacturing firms in Sri Lanka. Asian Social Science, 10(18): 50-62.

Woldie, A., P. Leighton and A. Adusua, 2008. Factors influencing small and medium enterprises (SMEs): An exploratory study of owner/manager and firm characteristics. Journal of Banks and Bank Systems, 3(3): 5-13.

Yordanova, D.I. and M.-A. Tarrazon, 2010. Gender differences in entrepreneurial intentions: Evidence from Bulgaria. Journal of Developmental Entrepreneurship, 15(03): 245-261. Available at: https://doi.org/10.1142/s 1084946710001543.

Citation | Ruth Elias; Wilhelm Leonard; Joshua Mwakujonga (2018). Determinants of Owner-manager Competencies for Small Business Operations: Evidence from a Small Restaurant Business in Tanzania. Asian Business Research Journal, 3: 41-47.

History:

Received: 31 August 2018

Accepted: 8 November 2018

Published: 4 December 2018

Licensed: This work is licensed under a Creative Commons

Attribution 3.0 License $($ (c) $)$

Publisher: Eastern Centre of Science and Education

Eastern Centre of Science and Education is not responsible or answerable for any loss, damage or liability, etc. caused in relation to/arising out of the use

Eastern Centre of Science and Education is not responsible or answerable for any loss
of the conten
Acknowledgement: All authors contributed to the conception and design of the study.

Funding: This study received no specific financial support.

Competing Interests: The authors declare that they have no conflict of interests.

Transparency: The authors confirm that the manuscript is an honest, accurate, and transparent account of the study was reported; that no vital features of the study have been omitted; and that any discrepancies from the study as planned have been explained.

Ethical: This study follows all ethical practices during writing. 